\title{
Removal of lindane from wastewater using liquid-liquid extraction process
}

\author{
Indrasing D.Patil ${ }^{1^{*}}$, Yogita S. Patil ${ }^{2}$, Bhausaheb L. Pangarkar ${ }^{3}$ \\ ${ }^{1}$ Affiliated to North Maharashtra University, Department of Biotechnology, Bambhori, Jalgaon, India- 425001 \\ ${ }^{2}$ Govt. College of Engineering, Applied Science Dept., Jalgaon, India \\ ${ }^{3}$ Affiliated to University of Pune, Sir Visvesvaraya Institute of Technology, Nashik, India \\ * Corresponding author: e-mail: idp72@yahoo.co.in
}

\begin{abstract}
Pesticide pollution is a serious problem being faced. Harmful levels of pesticides are found in the water which is used for daily purposes. In the event of such a scenario, this paper presents a working solution for bringing down the Pesticide levels in the water to safe levels by using the method of liquid-liquid extraction. The experimental liquid-liquid equilibrium data on pesticide-water-solvent ternary mixtures at a temperature of $288.15 \mathrm{~K}$ are presented here. The pesticide used here is a chlorinated hydrocarbon called lindane found in the water (underground, land), beverages and foods. The solvents used are Petro-ether-Chloroform (1:1), Ethylene di chloride and n-hexane. The equilibrium generation diagram, triangular diagram, tie lines and bimodal curves as well as the distribution coefficient have been determined and reported. The petro-ether-chloroform was found to be the right solvent for the separation of lindane from wastewater because of high selectivity (25.36) and distribution coefficient (4). The extraction process is simulated into ' $\mathrm{C}$ ' language.
\end{abstract}

Keywords: lindane, extraction, ternary diagram, wastewater treatment.

\section{INTRODUCTION}

Lindane $(1,2,3,4,5,6$ - hexachlorocyclohexane, $\gamma-\mathrm{HCH})$ is a broad-spectrum organochlorine pesticide. It is a Persistent Organic Pollutant (POP), potent carcinogen and teratogen and classified by the World Health Organization (WHO) as 'moderately hazardous' and permissive limit in drinking water is $2 \mu \mathrm{g} / \mathrm{l}$. Residues of lindane have been detected in drinking water sources and beverages as well as in foods ${ }^{1}$. The chemical analysis of branded packaged drinking water (commonly known as mineral water) conducted by the Center for Science and Environment, New Delhi, India, has revealed that bottled water of all the major brands contain high doses of pesticide residue $^{2}$. Lindane is used as an insecticide on fruit and vegetable crops (including greenhouse vegetables and tobacco), for seed treatment and in forestry. It is also used as a therapeutic pesticide (e.g., in the treatment of scabies) in humans and animals. Several countries have restricted the use of lindane. Lindane enters water from direct application for the control of mosquitoes, from use in agriculture and forestry, from precipitation and, to a lesser extent, from occasional contamination of wastewater from manufacturing plants. Normal levels in precipitation are $0.4-155 \mu \mathrm{g} / \mathrm{L}$, but levels up to $43 \mu \mathrm{g} / \mathrm{L}$ have been measured in India ${ }^{3}$.

Lindane has been listed as a pollutant of concern to EPA's Great Water Program due to its persistence in the environment, potential to bioaccumulation, and toxicity to humans and the environment ${ }^{4}$.The major effects noted from oral exposure to lindane in humans are on the nervous system, liver, kidney, immune systems ${ }^{5,6}$. In animal studies from chronic oral exposure to lindane effects on the blood i.e. decrease in the number of red and white blood cells ${ }^{5,7}$. Also, decreased sperm count, increased testicular weight from oral exposure to lindane in animal. Disrupted ovarian cycling and reduced ovulation rate were reported in female animals exposed to lindane by gavages ${ }^{5,6}$.
Many researchers have used various methods for lindane removal from water such as the adsorption ${ }^{8-11}$, chemical degradation ${ }^{12-14}$, bioremediation ${ }^{15}$. Bagasse fly ash has been used by many researchers for the removal of lindane from water, ${ }^{8}$. Jovan and co-workers have used organo-zeolites for the removal of lindane from water includes use of microwave irradiation, degradation with $\mathrm{NaOH}$-modified sepiolite ${ }^{\mathbf{9}}$ and addition of hydrogen peroxide ${ }^{2}$. Many researchers have demonstrated the use of microbial cultures for the bioremediation of lindane. ${ }^{15}$ These methods could have several operational constraints, especially for the treatment of drinking water. For example, the addition of strong chemicals to drinking water supplies may not be acceptable. Adsorption of lindane on porous inorganic/organic material poses problem of the disposal of the adsorbed lindane. The important considerations in the use of a microbial processes for lindane degradation are, (i) the slow rate of biodegradation requiring a long period of time (24-100 h), (ii) possible pathogenic effects of the microorganisms used, and (iii) incomplete degradation of lindane resulting in more harmful degradation products. Among all these methods the liquid-liquid extraction is a simple and popular method here used for the removal of lindane from the water. No studies are available concerning the liquid - liquid extraction process for removal of lindane from aqueous solution or wastewater. Hence, yet it is not known about the use of solvents as well as the removal of lindane by the extraction process.

When the liquid solution and an insoluble solvent are brought into intimate contact, the constituents of the liquid mixture are distributed between the phases resulting into some degree of separation and then are separated from one another based on density difference. In liquid - liquid extraction, the main driving force is the distribution coefficient. This is conveniently shown on the distribution diagram, where the point $(\mathrm{E}, \mathrm{R})$ lies above the diagonal $y=x$. In the physical sciences, a partition $-(\mathrm{P})$ or distribution coefficient $\mathrm{D})$ is the ratio 
of concentrations of a compound in a mixture of two immiscible phases at equilibrium. Hence these coefficients are the measure of the difference in solubility of the compound in these two phases ${ }^{\mathbf{1 6}}$. Hence the distribution coefficient is defined as the following equation.

$D=C_{E} / C_{R}$

Where, $C_{E}$ is the solute concentration in the extract layer and $C_{R}$ is the solute concentration in the raffinate layer. Similarly the distribution coefficient (D) also defined in terms of the mass fraction ratio of the solute in raffinate $\left(X_{R}\right)$ and extract $\left(X_{E}\right)$ by using the following equation.

$D=X_{E} / X_{R}$

Also, the selectivity $(K)$ is an important parameter for choosing a solvent for the extraction process. The selectivity is a measure of the effectiveness of the extraction solvent for separating the constituents of feed. If the selectivity is equal to unity, then separation by extraction is not possible ${ }^{16}$. It is determined by using the following equation.

$\mathrm{K}_{\mathrm{i}, \mathrm{j}}=\left[\mathrm{X}_{\mathrm{i}} / \mathrm{X}_{\mathrm{j}}\right]_{\mathrm{E}} /\left[\mathrm{X}_{\mathrm{i}} / \mathrm{X}_{\mathrm{j}}\right]_{\mathrm{R}}$

Where, $K_{i, j}$ is the selectivity of $i$ component with respect to $j$ component; $X$ is the mass fraction of $i$ and $j$ component in extract $(E)$ and raffinate $(R)$ phase.

\section{MATERIAL AND METHOD}

\section{Material}

petro-ether, chloroform, n-hexane and ethylene dichloride (EDC) were supplied from Qualigens chem. Ltd, Mumbai. The physical and chemical properties are listed in Table 1. The pesticide is lindane, a $\gamma$-isomer of benzene hexachloride manufactured and supplied by IFFCO and its structural formula is shown in Fig. 1

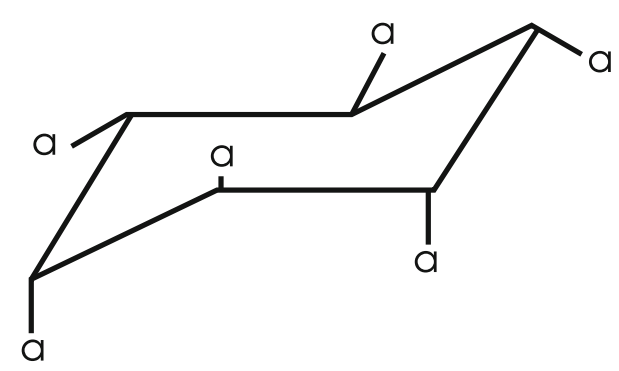

Figure 1. Chemical structure formula of lindane and typical properties are also shown in Table 1 . The experimental points that define the solubility curves were determined by an equilibrium cell equipped with a magnetic stirrer and an isothermal outer beaker as a jacket to the set up. The inner temperature of the cell $\left(20^{\circ} \mathrm{C}\right)$ was measured within an accuracy of $\pm 0.5^{\circ} \mathrm{C}$ by mercury thermometer.

\section{Method}

The $500 \mathrm{ml}$ beaker was filled with heterogeneous waterpesticide mixture prepared by weighing in an electronic citizen balance. The solvent was added by means of a burette. The end-point was determined by observing the transition from a clear solution to the cloud-like appearance (cloud point titration). This pattern was convenient for providing the water-rich side of the curves. On the other hand, the data for the solvent-rich side of the curves were obtained by titrating the pesticide-solvent mixture with water until turbidity appears. Composition determinations were accurate to \pm .005 mass fractions. The solubility of water and solvent were determined by applying a synthetic method. A weighed amount of the first substance was introduced into the cell; the second was added until permanent heterogeneity was observed.

The tie line data determinations were obtained using the equilibrium apparatus described above. A variety of mixtures i.e. pesticide (lindane), solvents (n-hexane, ethylene dichloride, petro-ether and chloroform) and water were prepared for an experimental purpose. The cell was filled with each of these mixtures and vigorously stirred for 1 hour under isothermal conditions. After the stirring was turned off, the contents were immediately introduced into the separating funnel. After complete separation of the phases, a suitable amount of each layer was recovered for analysis. The chloride contents of the sample were determined by volumetric back titrating the raffinate layer with $\mathrm{NH}_{4} \mathrm{SCN}$ solution using alum as an indicator. The end point of the titration occurred when a faint reddish colour appeared. Several check determinations on the samples showed the accuracy of the method was within \pm 0.2 of the mass fraction. The distribution coefficient of lindane determined by using eq. (2) for solvents such as n-hexane, ethylene dichloride and petro-ether-chloroform. The mass ratio was 1:1 for the preparation of the mixture of petro-ether and chloroform which are used as a solvent.

Table 1. Physical and chemical properties of solvents and lindane

\begin{tabular}{|c|c|c|c|c|}
\hline Property & $\mathrm{n}-\mathrm{Hexane}^{17}$ & Ethylene dichloride (EDC) ${ }^{18}$ & $\begin{array}{c}\text { Petro-ether - chloroform } \\
(1: 1)\end{array}$ & Lindane $^{19,20}$ \\
\hline $\begin{array}{l}\text { Molecular } \\
\text { Formula }\end{array}$ & $\mathrm{C}_{6} \mathrm{H}_{14}$ & $\mathrm{CH}_{2} \mathrm{Cl}-\mathrm{CH}_{2} \mathrm{Cl}$ & $\mathrm{C}_{2} \mathrm{H}_{5}-\mathrm{O}-\mathrm{C}_{2} \mathrm{H}_{5}$ and $\mathrm{CHCl}_{3}$ & $\mathrm{C}_{6} \mathrm{H}_{6} \mathrm{Cl}_{6}$ \\
\hline Molecular weight & $86.183 \mathrm{~g} / \mathrm{g}-\mathrm{mol}$ & $98.96 \mathrm{~g} / \mathrm{g}-\mathrm{mol}$ & Avg. Mol. Wt. $91.4 \mathrm{~g} / \mathrm{g}-\mathrm{mol}$ & $290.85 \mathrm{~g} / \mathrm{g}-\mathrm{mol}$ \\
\hline Appearance & Colourless liquid, & $\begin{array}{c}\text { Colourless viscous liquid, } \\
\text { hygroscopic }\end{array}$ & Colourless liquid & Colourless solid \\
\hline $\begin{array}{l}\text { Odour } \\
\text { description }\end{array}$ & Gasoline like smell & Characteristic odour & Greasy petroleum smell & Odourless crystal \\
\hline Vapour Density & $2.97 \mathrm{~g} / \mathrm{l}$ & $3.5 \mathrm{~g} / \mathrm{l}$ & - & - \\
\hline $\begin{array}{l}\text { Density and } \\
\text { Phase }\end{array}$ & $0.6548 \mathrm{~g} / \mathrm{ml}$, liquid & $1.253 \mathrm{~g} / \mathrm{ml}$, liquid & $1.165 \mathrm{~g} / \mathrm{ml}$, liquid & $1.85 \mathrm{~g} / \mathrm{ml}$, solid \\
\hline Melting point & $-95^{\circ} \mathrm{C}(178 \mathrm{~K})$ & $-35^{\circ} \mathrm{C}(238 \mathrm{~K})$ & $6.55^{\circ} \mathrm{C}(279.5 \mathrm{~K})$ & - \\
\hline Boiling Point & $69^{\circ} \mathrm{C}(342 \mathrm{~K})$ & $83.48^{\circ} \mathrm{C}(356.48 \mathrm{~K})$ & $80.74^{\circ} \mathrm{C} \quad(353.74 \mathrm{~K})$ & $323.4^{\circ} \mathrm{C} \quad(596.4 \mathrm{~K})$ \\
\hline Viscosity & $0.294 \mathrm{cP}$ at $25^{\circ} \mathrm{C}$ & $0.79 \mathrm{cP}$ at $20^{\circ} \mathrm{C}$ & $1.02 \mathrm{cP}$ at $17^{\circ} \mathrm{C}$ & $10 \mathrm{mPa}$ \\
\hline Solubility & $\begin{array}{c}\text { In water } 9.5 \mathrm{mg} / \mathrm{L} \text { at } \\
20^{\circ} \mathrm{C}\end{array}$ & $\begin{array}{c}\text { In water } 0.87 \mathrm{~g} / 100 \mathrm{ml} \text { of water } \\
\text { at } 20^{\circ} \mathrm{C}\end{array}$ & $\begin{array}{c}\text { Water immiscible, ethanol } \\
\text { miscible }\end{array}$ & $\begin{array}{c}\text { In water } 7.3-7.8 \mathrm{mg} / \mathrm{L} \text { at } \\
20^{\circ} \mathrm{C}\end{array}$ \\
\hline Refractive index & 1.375 at $34.4^{\circ} \mathrm{C}$ & 1.4448 at $20^{\circ} \mathrm{C}$ & 1.423 & 1.5299 at $123^{\circ} \mathrm{C}$ \\
\hline
\end{tabular}




\section{RESULTS AND DISCUSSION}

The ternary liquid-liquid equilibrium curves were shown in Figs. 2 to 4 for the systems lindane - water - n-hexane, lindane - water - EDC and lindane - water - petro-ether-chloroform respectively. The effectiveness of the solvent for the separation of water and solution of lindane pesticide into its components is measured by comparing the ratio of lindane to water in solvent rich phase to that in the water rich phase at equilibrium. The selection of the solvent in the extraction process is very important. So, these 03 solvents were chosen due to the properties of the solvents (Table 1) such as the stability, less water solubility and high selectivity. For all useful extraction operations the selectivity must exceed unity, the more so better. The selectivity of the n-hexane, EDC and petro-ether-chloroform were found as $15.74,9.81$ and 25.36 respectively by using eq. (3). It is not necessary that the distribution coefficient be larger than 1 , large values are very desirable since less solvent will then be required for the extraction. The distribution coefficients of these three systems were determined from Figs. 2 to 4 . These figure shows that the solvent rich phase, i.e. the extract phase

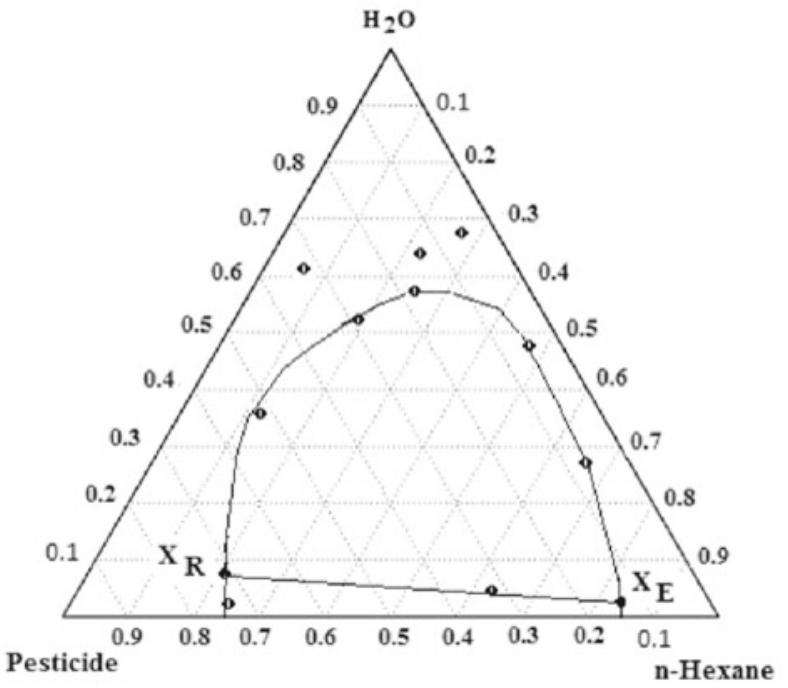

Figure 2. Ternary liquid-liquid equilibria (mass fraction) for pesticide (lindane) + water $+n$ - hexane (solvent)

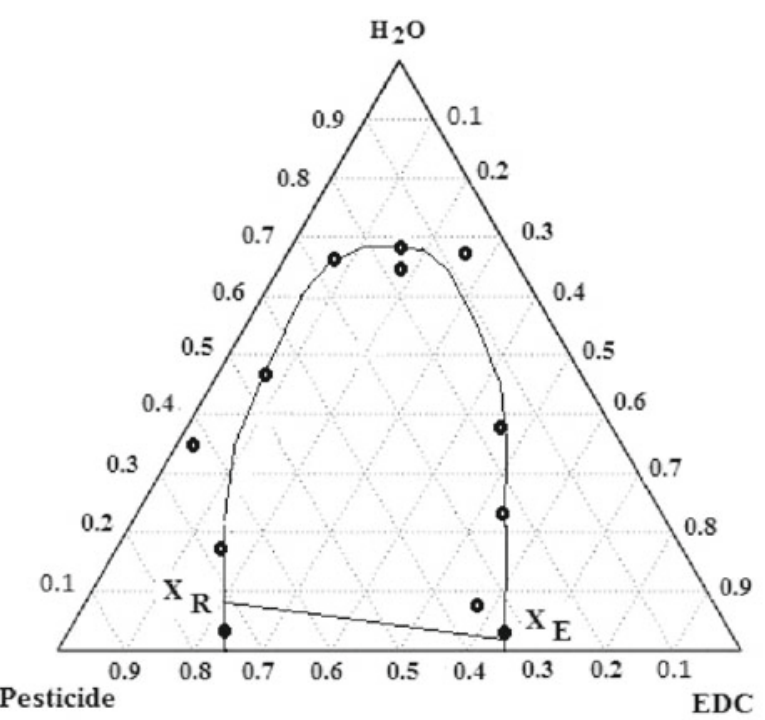

Figure 3. Ternary liquid-liquid equilibria (mass fraction) for pesticide (lindane) + water + ethylene dichloride (solvent)

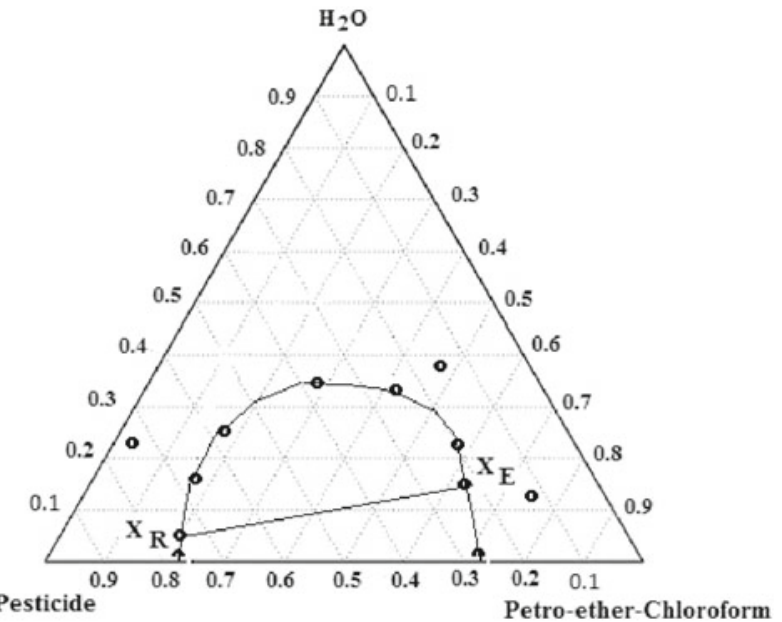

Figure 4. Ternary liquid-liquid equilibria (mass fraction) for pesticide (lindane) +water + petro-ether- chloroform $(1: 1)$

removes the lindane from water. The lindane concentration in terms of mass fraction in the extract phase was higher by using the solvent is petro-ether-chloroform (1:1). The distribution coefficient is found 4 for this solvent. The n-hexane and EDC gives fewere distribution coefficients such as 0.5 and 0.25 , respectively. It means these solvents give the lesser performance for the removal of lindane from water. Hence the petro-ether-chloroform (1:1) is the better solvent used for the removal of lindane from the water and the separation reaches up to $96 \%$. Due to a high selectivity and high distribution coefficient, the petro-ether-chloroform is a suitable solvent found for the removal of lindane from water by the extraction process.

From the cited literatures, the adsorption process is effective only with lower concentration. The bioremediation and degradation processes are very complicated and useful only at controlled parameters such as temperature. The extraction is a very simple, useful and alternative process used for the removal of lindane from industrial wastewater.

Simple simulation programs were developed for the determination of distribution coefficient in ' $\mathrm{C}$ ' language and shown in Appendix-I. The distribution coefficient of the petro-ether-chloroform was determined by this program and found 4.32 which is nearly equal to the experimental value. Hence, the computer program can be used easily for the selection of solvents for extraction process by comparing the distribution coefficients of various solvents.

\section{CONCLUSIONS}

Lindane is a very hazardous pesticide detected in drinking water sources, beverages and foods. It is removed from water by using the liquid-liquid extraction process. Choosing the solvent for better extraction is important. Hence 03 solvents such as n-hexane, ethylene dichloride and petro-ether-chloroform were used for the extraction process. The distribution coefficients were determined for each system and found the petro-ether-chloroform suitable solvent for the extraction of lindane from water and the separation reached up to $96 \%$. The distribution coefficient was found 4. Also, the generalized program in ' $C$ ' language gives a wide application in choosing a suitable solvent for a particular extraction process. The generalized program is very obvious and can be used by user efficiently. 


\section{LITERATURE CITED}

1. Anon. (2003). How safe is our bottled water? Down Earth, vol. 11 , no. 18 , p. $27-32$.

2. Anon. (2003). All major cold drink brands in India have pesticide residues, Down Earth, vol. 12 no. 6, p. 31-35.

3. WHO. (2004). Guidelines for drinking water quality. (http:// www.who.int/water_sanitation_health/dwg/chemical/lindane.pdf)

4. U.S. Environmental Protection Agency. (1994). Deposition of Air Pollutants to the Great Waters. First Report to Congress. EPA-453/R-93-055. Office of Air Quality Planning and Standards, Research Triangle Park, NC.

5. Agency for Toxic Substances and Disease Registry (ATSDR). (1997). Toxicological Profile for Alpha-, Beta-, Gamma-, and Delta- Hexachlorocyclohexane (Update). Draft for Public Comment. U.S. Public Health Service, U.S. Department of Health and Human Services, Atlanta, GA.

6. U.S. Department of Health and Human Services. (1993) Hazardous Substances Databank (HSDB, online database). National Toxicology Information Program, National Library of Medicine, Bethesda, MD.

7. U.S. Environmental Protection Agency. (1999). Integrated Risk Information System (IRIS) on gamma-Hexachlorocyclohexane. National Center for Environmental Assessment, Office of Research and Development, Washington, DC.

8. Gupta, V., Jain, C., Imran, A., Chandra, S. \& Agarwal, S. (2002). Removal of lindane and mathion from wastewater using bagasse fly ash-a sugar industry waste, water research, vol. 36, (10), p. 2483-2490, PII: S0043-1354(01)00474-2.

9. Jovan, L., Divna, K. \& Magdalena, T. et al., (2006) Removal of atrazine, lindane and diazinone from water by organo-zeolites, water research, vol. 40, p. 1079-1085, DOI: 10.1016/j.watres.2006.01.001

10. Hassan, A., Abed, M. \& Ismael, A. (2009). Removal of lindane and melathion from wastewater by activated carbon prepeared from apricot stone, Ass. Univ. Bull. Environ. Res., vol. 12, (2), p. 1-8.

11. Sumipa, D. \& Chaudhari, S. (2012). Potentiality of sugarcane baggasse as an adsorbent for the removal of pesticides from drinking water, NeBIO, vol. 3, (2), p. 107-111.

12. Kipopoulou, A., Zouboulis, A., Samara, C. \& Kouimtzis, T. (2004). The fate of lindane in the conventional activated sludge treatment process, Chemosphere, vol. 55, p. 81-91, DOI: 10.1016/j.chemosphere.2003.11.020.

13. Veena, S. \& Singh, D. (2011). Biodegradation of lindane pesticide by non white-rots soil fungus Fusarium sp, World J. of Micro and Biotech, vol. 27, (8), p. 1747-1754.

14. Zheng, G., Selvam, A. \& Wang, J. (2011). Rapid degradation of lindane ( $\gamma$-hexachlorocyclohexane) at low temperature by sphingobium strains, Int. J. Biodet. \& Biodegrd., vol. 65, (4), p. 612-618. DOI: 10.1016/j.ibiod.2011.03.005.

15. Jaseetha, A. \& Nilanjana, D. (2012). Remediation of lindane from environment - an overview, vol. 2, (1), p. 9-15.

16. Robert, E.T. (1981). Mass Transfer Operations, $3^{\text {rd }}$ edition, Mcgraw-Hill International series, p. 482-500.

17. http://en.wikipedia.org/wiki/Hexane

18. http://macro.lsu.edu/HowTo/solvents/dcm.htm

19. http://ces.iisc.ernet.in/energy/HC270799/HDL/ENV/enven/ vol346.htm

20. http://www.microkat.gr/msds/lindane.htm

\section{Appendix-I}

/* SIMULATION OF LIQUID-LIQUID EXTRACTION*/ \#include $<$ stdio.h $>$ \#include $<$ conio.h $>$ \#include $<$ math.h $>$ void main() \{

float i,m,m1,m2,m3,w1,w2,w3,e,r,me,mr,mce,mcr,ce,cr,de,d r,Ewt =74.08,ne,nr,D,Xe,Xr;

int ch;

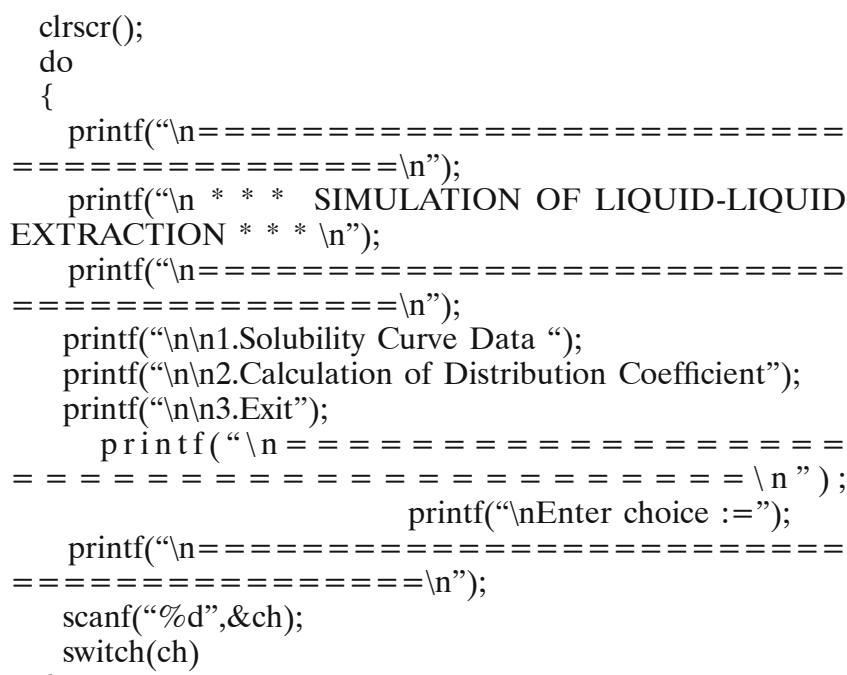

